\title{
RESPONSE OF LEY PLANTS TO ROCK PHOSPHATE AND SUPERPHOSPHATE
}

\author{
Armi KaILA \\ University of Helsinki, Department of Agricultural Chemistry \\ and \\ Pentti Hänninen \\ Agricultural Research Centre, Movable field experiments in Central Finland
}

Received December 14, 1959.

The ability of plants to feed on rock phosphate has been studied since the last century. Prianischnikow (24) emphasized the fact that there are, in this respect, great differences between various plant groups. He stated that phosphorus in rock phosphate is almost unavailable for cereals, whereas some legumes, buckwheat, and mustard are able to utilize it even on non-acid soils and without the aid of physiologically acid nitrogen fertilizers. TRUOG (31) proposed that the ability of plants to use phosphorus from rock phosphate is related to their requirement of calcium, and, only in acid soils, it is possible for plants of a low calcium content to feed more advantageously on rock phosphate. Results reported by several authors mainly corroborate these claims $(2,5,7,11,21,33$ etc.).

A great deal of attention has been paid to the factors affecting the dissolution of rock phosphate phosphorus in soils. In general, there is no divergence in opinion on the better effect of rock phosphate on soils with a low content of lime than on soils rich in lime. Recently, UlRich (32) in his theoretical discussion on the efficiency of rock phosphate enumerates the following factors which may enhance the availability of this fertilizer in soils with an acidity from $\mathrm{pH} 5.5$ to $\mathrm{pH} 6.5$. They are a high humus content, adequate moisture, and high metabolic activity of the rhizosphere with a consequent high rate of carbon dioxide production and mildly reducing conditions. Owing to these factors, it is likely that rock phosphates are more effective in grassland than in arable soils.

The results of field trials and pot experiments in which the phosphorus effect of rock phosphate has been compared to that of other phosphorus fertilizers, often 
show marked divergences. In addition to several other factors, this may be due to the large variation in the quality of rock phosphates used in the trials. Their softness, content of fluorine, and fineness are characteristics on which their value as a phosphorus fertilizer is likely to depend, although this dependence is not always quite consistent $(1,12,15,22,25)$. The rock phosphate mainly used in Finland since the war, is the so-called Hyperphosphate Reno, an extremely finely ground (90\% will pass the screen with meshes of $0.05 \mathrm{~mm}$ ) soft North African phosphate.

According to the average results of field trials in Finland, somewhat more than twice as much phosphorus in hyperphosphate as in superphosphate is needed to produce an equal increase in the yields, even in trials of long duration $(27,10)$. Also in Swedish trials hyperphosphate was found to be inferior to superphosphate in most cases (9). Only exceptionally, hyperphosphate has shown the same efficiency as superphosphate $(9,12,13,19)$.

In most cases, the availability of hyperphosphate and superphosphate are compared only on the basis of the increases in the yield of dry matter. This, however, is not enough. Dickman and DeTurk (1940) e.g. emphasize that also "P uptake must be determined and the percentage of $\mathrm{P}$ in tissues considered before any general conclusions regarding $\mathrm{P}$ fertility can be drawn". The results of a previous study (18) indicate that this is necessary when the effect of hyperphosphate is in question: in an acid fen peat soil in Leteensuo Experiment Station the annual surface dressing with $200 \mathrm{~kg} / \mathrm{ha}$ of superphosphate or $260 \mathrm{~kg} / \mathrm{ha}$ of hyperphosphate produced equal yields of hay, but the phosphorus content of the hyperphosphate hay was only about $65-70$ per cent of that of the superphosphate hay.

Since these observations seemed to be of importance, particularly as regards the fodder production, further study was considered necessary. This was possible to carry out when hay samples from two field trials in Central Finland were available in the summer 1959. The results of these analyses are reported in the present paper.

\section{The field trials}

The two field trials were started in 1954 according to the same experimental layout:

1. No phosphate

2. Superphosphate $200 \mathrm{~kg} / \mathrm{ha}$ annually

3. Hyperphosphate Reno in quantities corresponding to the amount of phosphorus in superphosphate

The hyperphosphate was applied annually to the cereals and as a store dressing to the nurse crop for the three ley-years.

According to the commercial analyses the superphosphate contained citratesoluble $\mathrm{P}_{2} \mathrm{O}_{5}$ from 18 to 19 per cent, and the total amount of $\mathrm{P}_{2} \mathrm{O}_{5}$ in the hyperphosphate varied from 28 to 30 per cent.

As a basal dressing $100 \mathrm{~kg} / \mathrm{ha}$ of $50 \%$ potash fertilizer and $100 \mathrm{~kg} / \mathrm{ha}$ of nitrochalk were applied annually. Only the nurse crop was left without a nitrogen treatment. 
The total area of the experimental plots was $50 \mathrm{~m}^{2}$. The treatments were in randomized blocks replicated four times.

The experimental crops in the trial K 104 were wheat, oats, oats, and three years of red clover-timothy ley, those in the trial K 105 were oats, barley, oats, and three years of red clover-timothy ley.

The soils of these field trials are characterized by the analytical results reported in Table 1. The soil samples were collected in 1954 before the experiments were started.

Table 1. Soils of the field trials

\begin{tabular}{|c|c|c|}
\hline Soil & $\begin{array}{c}\text { K } 104 \\
\text { fine sand }\end{array}$ & $\begin{array}{c}\text { K } 105 \\
\text { humus soil }\end{array}$ \\
\hline $\mathrm{pH}_{\mathbf{H}} \mathrm{o}$ & 5.5 & 6.0 \\
\hline $\mathrm{pH}_{\mathrm{KCl}}^{2}$ & 4.6 & 5.3 \\
\hline Org. C \% & 3.4 & 12.0 \\
\hline Exchangeable $\mathrm{Ca}$ ppm & 1170 & 3520 \\
\hline Mg ppm & 110 & 380 \\
\hline $\mathrm{K}$ ppm & 100 & 220 \\
\hline Fe soluble in $0.1 \mathrm{~N} \mathrm{HCl}$, ppm & 420 & 540 \\
\hline$-\quad$ ppm & 1060 & 1630 \\
\hline $\mathrm{H}_{2} \mathrm{O}$-soluble P ppm & 4 & 5 \\
\hline $\mathrm{P}$ soluble in $0.03 \mathrm{~N} \mathrm{NH} \mathrm{NH}_{4} \mathrm{~F}+0.25 \mathrm{~N} \mathrm{HCl}$, ppm & 16 & 18 \\
\hline $\mathrm{P}-\quad 0.5 \mathrm{~N}$ acetic acid, ppm & 9 & 30 \\
\hline $\mathrm{P}--\quad 0.1 \mathrm{~N} \mathrm{HCl}, \mathrm{ppm}$ & 168 & 287 \\
\hline Exchangeable $\mathrm{P}$ ppm & 124 & 131 \\
\hline $\mathrm{P}$, in soil solutions $\mathrm{mg} / \mathrm{l}$ & 0.33 & 0.37 \\
\hline Indicator of the sorption capacity of $\mathrm{P}$ & 188 & 204 \\
\hline
\end{tabular}

The fine sand soil of experiment K 104 is distinctly more acid than the humus soil of trial K 105. The latter also appears to be richer in exchangeable calcium, magnesium, and potassium as well as in acid-soluble iron and aluminum, when these data are expressed on the weight basis. The various test values for phosphorus seem to indicate that in the humus soil of K 105 calcium dominates whereas in the more acid fine sand soil of K 104 aluminum and iron probably determine tha availability and retention of phosphate. This may be concluded from the facts that the acid soluble phosphorus is markedly higher in the humus soil than in the mineral soil, but the data obtained by the methods of BRAY and KuRTz (3) and TERÄSVUORI (28) are almost equal for the two soils. The phosphorus condition in the soil of trial K 105 is apparently somewhat better that in the soil of trial K 104 .

In the first two experimental years the cereals in trial K 104 responded to superphosphate but hyperphosphate did not increase their yields. In trial $\mathrm{K} 105$ no effect of the phosphate treatments could be detected. The total yields for four subsequent years including the nurse crop and the three harvests from the red clovertimothy ley were the following, expressed as feed units per hectars and as relative numbers: 


\begin{tabular}{|c|c|c|c|c|c|}
\hline \multirow{2}{*}{\multicolumn{2}{|c|}{ Treatment }} & \multicolumn{2}{|c|}{ K 104} & \multicolumn{2}{|c|}{ K 105} \\
\hline & & f.u./ha & rel. & f.u./ha & rel: \\
\hline No phosphate & & 9210 & 100 & 13280 & 100 \\
\hline Superphosphate & & 10450 & 113 & 14420 & 109 \\
\hline Hyperphosphate & & 10430 & 113 & 14050 & 106 \\
\hline L.S.D. $5 \%$ & . & 330 & & 520 & \\
\hline
\end{tabular}

Thus, in both trials there is a distinct response to the phosphate treatments, but no significant difference exists between the effects of superphosphate and hyperphosphate on the total yields.

\section{Analyses of hay samples}

Owing to the fact that a store dressing of hyperphosphate had to be used for the ley in order to avoid the abnormal application of this fertilizer as a surface dressing, first in the sixth year the total amounts of superphosphate phosphorus and hyperphosphate phosphorus applied to the soils were again equal. Therefore the hay yields of the third ley-year were taken as the object of a more detailed study. Hay samples were analysed separately from each plot.

The data reported in Table 2 show that in experiment K 104 the hay yields harvested from the plots treated with the two phosphate fertilizers were equal and significantly higher than that from the untreated plots. No statistically significant differences exist between the hay yields from the various treatments in experiment $\mathrm{K} 105$.

In trial $\mathrm{K} \mathrm{104,} \mathrm{the} \mathrm{content} \mathrm{of} \mathrm{red} \mathrm{clover} \mathrm{in} \mathrm{the} \mathrm{hay} \mathrm{was} \mathrm{not} \mathrm{high,} \mathrm{and} \mathrm{there}$ were no differences between the variously treated plots in this respect. In experi-

Table 2. Hay yield in 1959

\begin{tabular}{lcccc}
\hline Treatment & Dry matter & $\begin{array}{c}\text { Per cent } \\
\text { of } \\
\text { clover }\end{array}$ & & \multicolumn{2}{c}{ P in yield } \\
\cline { 4 - 5 } & $\mathrm{kg} / \mathrm{ha}$ & $\mathrm{g} / \mathrm{kg}$ & $\mathrm{kg} / \mathrm{ha}$ \\
\hline & Experiment & $\mathrm{K} 104$ & & \\
No phosphate & 3960 & 11 & 1.47 & 5.8 \\
Superphosphate & 4900 & 16 & 2.06 & 10.1 \\
Hyperphosphate Reno & 4850 & 14 & 1.66 & 8.1 \\
\hline L.S.D. 5\% & 200 & 8 & 0.16 & 0.6 \\
& & & & \\
No phosphate & 5880 & 5 & 1.57 & 9.2 \\
Superphosphate & 6120 & 2 & 2.07 & 12.7 \\
Hyperphosphate Reno & 6070 & 7 & 1.67 & 10.1 \\
\hline L.S.D. 5\% & 770 & 4 & 0.28 & 2.3 \\
\hline
\end{tabular}


ment $\mathrm{K} \mathrm{105}$, there is even less clover, and it is questionable whether any significance has to be given to the somewhat higher content of clover in the hyperphosphate hay as compared to that in the superphosphate hay.

The most interesting figures in this table are those expressing the total content of phosphorus in the hay. While the treatment of superphosphate has increased the phosphorus content by about 30 to 40 per cent, or from 1.47 and $1.57 \mathrm{~g} / \mathrm{kg}$ to about $2.1 \mathrm{~g} / \mathrm{kg}$, the increase produced by hyperphosphate dressing is not much more than 10 per cent in trial K 104 and insignificant in trial K 105. Also the total amounts of phosphorus in the harvested hay yields are in both of the trials markedly lower in the hyperphosphate hay than in the superphosphate hay.

In order to test whether there are any differences in the ability of the various ley plants to use superphosphate and hyperphosphate, the samples of red clover and the grasses were analyzed separately. The grasses consisted almost exclusively of timothy.

Table 3. Phosphorus content of red clover and grasses in the hay

\begin{tabular}{|c|c|c|c|c|}
\hline \multirow[t]{2}{*}{ Treatment } & \multicolumn{2}{|c|}{$\begin{array}{l}\text { Experiment } \mathrm{K} 104 \\
\mathrm{P} \text { g/kg }\end{array}$} & \multicolumn{2}{|c|}{$\begin{array}{c}\text { Experiment } \mathrm{K} 105 \\
\mathrm{P} \text { g/kg }\end{array}$} \\
\hline & clover & grasses & clover & grasses \\
\hline No phosphate & 1.73 & 1.44 & 1.76 & 1.56 \\
\hline Superphosphate & 2.04 & 2.07 & $(2.40)^{*}$ & 2.07 \\
\hline Hyperphosphate Reno & 2.03 & 1.60 & 2.04 & 1.64 \\
\hline L.S.D. $5 \%$ & 0.14 & 0.14 & 0.50 & 0.30 \\
\hline
\end{tabular}

* An average for two replicate plots only

The data in Table 3 corroborate the opinion that the legumes are, in general, better feeders on rock phosphate than are the graminaceous plants. In experiment $\mathrm{K} 104$, the phosphorus content of clover is equal in the hay produced by superphosphate and in that produced by hyperphosphate. Owing to the very low clover content in the hay from trial $\mathrm{K} 105$, the analytical data for clover in this experiment are less reliable. On the other hand, the figures for the phosphorus content of timothy in both trials quite distinctly show that this plant was not able to take up phosphorus from hyperphosphate even approximately as well as from superphosphate.

The phosphorus economy of the ley plants was further studied by performing a simple fractionation of the phosphorus (17). Unfortunately, samples of clover from trial K 105 were no longer available for this analysis. The phosphorus fractions are expressed by the figures in Table 4 .

The effect of the phosphate treatments may be detected almost exclusively in the fraction of inorganic phosphorus soluble in $0.5 \mathrm{~N}$ hydrochloric acid. In all the samples the amount of phosphorus extracted by boiling ethanol was very low and equal for all the treatments. The phosphorus in the acid-insoluble residue, 
Table 4. Phosphorus fractions in the plants

(Expressed as $\mathrm{P} \mathrm{g} / \mathrm{kg}$ )

$\begin{array}{ccccc} & \text { a } & \text { b } & \text { c } & \text { d } \\ & \text { P in } & \text { Inorg. P } & \text { Org. P } & \text { P } \\ \text { Plant and treatment } & \text { ethanol } & \text { soluble in } & \text { soluble in } & \text { insoluble a+c d } \\ & \text { extract } & 0.5 \mathrm{~N} \mathrm{HCl} & 0.5 \mathrm{~N} \mathrm{HCl} & \text { in } 0.5 \mathrm{~N} \mathrm{HCl}\end{array}$

Experiment K 104

Red clover

No phosphate

Superphosphate

Hyperphosphate

Grasses

No phosphate

Superphosphate

0.04

0.82

0.29

0.59

0.92

0.04

1.06

0.32

0.60

0.96

0.04

1.01

0.33

0.61

0.97

Hyperphosphate

0.04

0.79

0.30

0.34

0.68

0.05

1.30

0.37

0.37

0.79

$\begin{array}{rll}\text { Hyperphosphate } & 0.05 & 0.94 \\ \text { L.S.D. } 5 \% & 0.005 & 0.06\end{array}$

0.94

0.32

0.34

0.71

\section{Experiment K 105}

Grasses

\begin{tabular}{llllll} 
No phosphate & 0.06 & 0.81 & 0.17 & 0.49 & 0.72 \\
Superphosphate & 0.07 & 1.15 & 0.21 & 0.50 & 0.78 \\
Hyperphosphate & 0.06 & 0.81 & 0.16 & 0.50 & 0.72 \\
\hline L.S.D. 5\% & 0.01 & 0.13 & 0.03 & 0.08 & 0.08 \\
\hline
\end{tabular}

although higher for red clover than timothy, did not show any divergence due to the treatment. In the fraction of acid-soluble organic phosphorus a very slight tendency towards a higher value in the grasses from the superphosphate plots may be observed. The sum of phosphorus in the three fractions which mostly represent organic phosphorus compounds is equal for the variously treated red clover samples and timothy samples, respectively. Thus the differences in the content of total phosphorus of these plants are due to an accumulation of inorganic phosphorus or phosphorus determined as inorganic in this fractionation procedure. This result is in accordance with the earlier observation (18).

It would be of interest to find out whether a higher content of phosphorus in the cells has exerted any effect on the other constituents of the plants. The hay samples were analysed for their contents of ash, calcium, potassium, and nitrogen. The results recorded in Table 5 only indicate the typical difference between the red clover and timothy in their content of ash, calcium, and nitrogen, but no effect of the various treatments may be found.

\section{Discussion}

In the field trial at Leteensuo Experiment Station (18) on account of which the present study was carried out, the amount of phosphorus needed to give the same increase in yield was twice as high in the hyperphosphate as in the super- 
Table 5. The content of ash, calcium, potassium, and total nitrogen in the ley plants

\begin{tabular}{|c|c|c|c|c|}
\hline Plant and treatment & Ash \% & $\mathrm{Ca} \%$ & K \% & $\mathrm{N} \%$ \\
\hline \multirow{2}{*}{\multicolumn{5}{|c|}{$\begin{array}{l}\text { Experiment K } 104 \\
\text { Red clover }\end{array}$}} \\
\hline & & & & \\
\hline No phosphate & 7.0 & 1.72 & 1.63 & 2.42 \\
\hline Superphosphate & 7.6 & 1.62 & 1.65 & 2.46 \\
\hline Hyperphosphate & 7.6 & 1.65 & 1.85 & 2.49 \\
\hline \multicolumn{5}{|l|}{ Grasses } \\
\hline No phosphate & 4.8 & 0.51 & 1.61 & 1.11 \\
\hline Superphosphate & 4.8 & 0.51 & 1.56 & 1.20 \\
\hline Hyperphosphate & 4.9 & 0.46 & 1.54 & 1.17 \\
\hline L.S.D $5 \%$ & 0.9 & 0.05 & 0.34 & 0.17 \\
\hline \multicolumn{5}{|l|}{$\begin{array}{l}\text { Experiment K } 105 \\
\text { Grasses }\end{array}$} \\
\hline No phosphate & 4.4 & 0.44 & 1.40 & 1.53 \\
\hline Superphosphate & 4.4 & 0.45 & 1.44 & 1.40 \\
\hline Hyperphosphate & 4.4 & 0.50 & 1.43 & 1.61 \\
\hline L.S.D. $5 \%$ & 0.7 & 0.06 & 0.20 & 0.25 \\
\hline
\end{tabular}

phosphate. If the phosphorus yields are compared, this ratio is even more unfavourable: the effect of superphosphate phosphorus was 2.4-2.8 times higher than that of hyperphosphate phosphorus. In the present trials equal amounts of superphosphate phosphorus and hyperphosphate phosphorus produced an equal increase in yields. In this respect the trials do not seem to be quite typical: generally, hyperphosphate only seldom reaches the rate of efficiency of superphosphate.

It was supposed that the reason for the low phosphorus content of the hyperphosphate hay in the Leteensuo field trial could be found in the fact that hyperphosphate was applied as a surface dressing to the timothy ley. The results of the present trials show, however, that even when hyperphosphate is worked in, the graminaceous ley plants may be low in phosphorus. The phosphorus content of the grasses from the hyperphosphate plots was only $0.16 \% \mathrm{P}$ of dry matter which is markedly lower than the minimum phosphorus content of hay of good quality or about $0.22 \% \mathrm{P}(20)$. Thus, here is a problem worthy of attention from the point of view of animal nutrition.

A survey of the literature shows that in several field trials and pot experiments the graminaceous plants produced by rock phosphate had a lower phosphorus content than that produced by superphosphate, as well as a lower dry matter yield $(4,14,23,29,30)$. Red clover, on the other hand, has been able to build plant matter equally rich in phosphorus both when feeding on rock phosphate and on superphosphate (23).

The ability of red clover to use the phosphorus in rock phosphate may be explained on the basis of the theory proposed by TRUOG (31) that it is a plant high in calcium, or as DRAKe and Steckel (8) do, on the basis of the fairly high 
cation exchange capacity of its roots. In a previous study (16) the increase in the acidity of the soil under and after red clover as compared to the acidity in the timothy plots was demonstrated. This may be partly connected to the higher rate of nitrification found in the red clover soil. Probably also the microorganisms of the rhizosphere, known to be able to solubilise apatite (26) assist in the uptake of rock phosphate phosphorus.

Some authors have found in pot cultures that growing legumes in association with graminaceous plants improves the ability of the latter to feed on rock phosphates, owing to the intensive uptake of calcium by the legume roots $(7,8)$. If this also occurs in the field, it is possible that a ley rich in legumes may efficiently use rock phosphate. In every case, a high percentage of legumes in the mixture secures a satisfactory phosphorus content in the hay.

So far as the quality of hay as fodder is examined, a high phosphorus content is of importance. Yet, the question arises whether the plants themselves profit from this extra phosphorus, mostly accumulated as inorganic forms, which does not seem to be necessary for the production of a marked amount of dry matter. In the present trials the grasses feeding on hyperphosphate were able to synthesize plant material using $0.43-0.47 \mathrm{~g} / \mathrm{kg}$ less phosphorus than grasses feeding on superphosphate. It could be concluded that in the latter case a luxury consumption of phosphorus had occurred. This, however, is a problem of plant physiology which needs further study.

\section{$S u m m$ ary}

The results of two field trials in which the efficiency of superphosphate phosphorus and rock phosphate (Hyperphosphate Reno) phosphorus were compared on a fine sand soil and a humus soil, did not show any differences in the dry matter yields produced by the two fertilizers within the experimental period including the nurse crop and three years of ley.

The analyses of the hay yields harvested from the third year red clover-timothy ley, fairly poor in red clover, proved that the phosphorus content of the hay from the hyperphosphate plots was markedly lower than that of the hay from the superphosphate plots. The respective figures were 0.17 and 0.21 per cent $\mathrm{P}$ of dry matter, while the phosphorus content of the hay from the untreated plots was $0.15-0.16$ per cent.

Red clover seemed to be able to synthesize plant material equally rich in phosphorus both when feeding on superphosphate and when feeding on hyperphosphate. On the other hand, the grasses, in these cases mainly timothy, took up far less phosphorus from hyperphosphate than from superphosphate.

The differences in the phosphorus content of the respective plant groups were almost exclusively due to differences in their content of inorganic phosphorus, or phosphorus determined as inorganic forms by the simple fractionation procedure employed. 
No effect of the different phosphate treatments on the content of ash, calcium, potassium, or nitrogen in the ley plants could be detected.

The results of the present study corroborate the earlier observation that on a ley, poor in clover, rock phosphate may produce crops too low in phosphorus for the needs of domestic animals. The results also emphasize that it is important not to judge the response to phosphate fertilizers only on the basis of the dry matter yields.

\section{R E F E R E C E S}

(1) BARTholomew, R. P. 1935. Fluorine, its effect on plant growth, and its relation to the availability to plants of phosphorus in phosphate rock. Soil Sci. 40: 203-217.

(2) BAUER, F. C. 1921. The relation of organic matter and the feeding power of plants to the utilization of rock phosphate. Ibid. 12: 21-41.

(3) Bray, R. H. \& Kurtz, L. T. 1945. Determination of total, organic and available forms of phosphorus in soils. Ibid. 59: $39-45$.

(4) BRÜNE, Fr. 1948. Welche Böden eignen sich zur Düngung mit Rohphosphaten? Zeitschr. f. Pflanzenern., Düng. u. Bodenk. 41: 233-245.

(5) DeTurk, E. E. 1942. The problem of phosphate fertilizers. Ill. Agr. Exp. Sta. Bul. 484.

(6) Dickman, S. R. \& DeTurk, E. E. 1940. Response of young corn plants to inorganic phosphates differing in solubility I. Soil Sci. Soc. Amer. Proc. 5: 213-219.

(7) Dомолтоviтsch, M. \& Schestakow, A. 1928. Beiträge zur Frage über die Löslichmachung von Rohphosphat durch die Wurzeln der Kulturpflanzen. Zeitschr. f. Pflanzenern., Düng. u. Bodenk. 11: 108-112.

(8) Drake, M. \& Steckel, J. E. 1955. Solubilization of soil and rock phosphate as related to root cation exchange capacity. Soil Sci. Soc. Amer. Proc. 19: 449-450.

(9) FrAnCK, O. 1957. Jämförande försök med superfosfat, shyperfosfat Reno» och smältfosfat. Stat. Jordbr. förs., Medd. 79.

(10) - - 1958. Relative efficiency and substitution number of fertilizers. Bul. Docum. 24: 19-30.

(11) FrIED, M. 1953. The feeding power of plants for phosphate. Soil. Sci. Soc. Amer. Proc. 17: $357-359$.

(12) Gisiger, L. \& PUlver, H. 1953. Zur Unterscheidunsfrage der harten und weicherdigen Rohphosphate. Landw. Jb. Schweiz 2: 75-86.

(13) Hofmann, E. \& Amberger, A. 1953. Uber einer 5jährigen Gefässversuch mit weicherdigen Rohphosphaten auf Mineralboden zu Gras. Zeitschr. f. Pflanzenern., Düng. u. Bodenk. 62: $210-214$.

(14) Jessen, W. 1958. Gefässversuche zur Prüfung der Düngewirkung yon Calcium- und Magnesiumphosphaten. Die Phosphorsäure 18: 42-48.

(15) Joos, L. L. \& Велск, C. A. 1951. Availability of phosphate rock as affected by particle size and contact with bentonite and soil of different $\mathrm{pH}$-values. Soil Sci. Soc. Amer. Proc. 15: $69-75$,

(16) KaIlA, A. 1952. Influence of legumes upon soil fertility. Ann Acad. Sci. Fennicae A II 42.

(17) - 1952. Observations on the effect of nitrogen and phosphorus upon the humification of straw. Acta Agr. Fennica 78, 2.

(18) - - 1958. Effect of various kinds of phosphorus fertilizers on a peat soil. J. Sci. Agric. Soc. Finland 30: 213-222.

(19) LASKE, P. 1956. Untersuchungen über die langjährige Wirkung weicherdiger, nordafrikanischer Rohphosphate zu mehreren Feldfrüchten. Landw. Forsch. 8: 207-212.

(20) - - 1956. Langjährige Wiesendüngungsversuche mit weicherdigen nordafrikanischen Rohphosphaten auf sauren Mineralböden. Ibid 9: 19-24.

(21) Lemmermann, O. \& Rauterberg, E. 1949. Über die Ausnutzung schwerlöslicher Phosphorsäure durch sogenannten Tiefwurzler und Flachwurzler nebst einigen anderen Frage der Stoffaufnahme. Zeitschr. f. Pflanzenern., Düng. Bodenk. 43: 1-18. 
(22) LundBlad, K. 1957. Rock phosphates, and comparative trials with such kinds of fertilizers in organic soils. Stat. Jordbr. förs., Medd. 80. Stockholm.

(23) Murdock, J. T. \& SEAY, W. A. 1955. The availability to greenhouse crops of rock phosphate phosphorus and calcium in superphosphate-rock phosphate mixtures. Soil. Sci. Soc. Amer. Proc. 19: 199-203.

(24) Prianischnikow, D. 1902. Zur Frage über den relativen Wert von verschiedenen Phosphaten. Landw. Ve:suchsst. 56: 107-140.

(25) Rowann, P. A. \& DeKleermacken, K. J. B. 1954. Natuurlig fosfaat als fosforzuurmeststof. Landbouwl: Tijdschr. 66: $231-234$.

(26) Sperber, J. I. 195\%. Incidence of apatite-solubilising organisms in rhizosphere and soil. Aust. J. Agric. Fes. 9: 778-781.

(27) TAINIO, A. 1958. Hienofosfaatin lannoitusarvosta superfosfaattiin verrattuna. (Ref. Uber den Düngungswert feingemahlenen weichen Rohphosphats (Renophosphat) im Vergleich mit Superphosphat.) Staatl. Landw. Versuchstätigkeit, Veröff. Nr. 168., Helsinki.

(28) TERĀSvuORI, A. 1954. Ủber die Anwendung saurer Extraktionslösungen zur Bestimmung des Phosphordiingerbedarfs des Bodens, nebst theoretischen Erörterungen über den Phosphorzustand des Bodens. Ibid, Nr. 141, Helsinki.

(29) Thun, R. 1939. U’’er das Wirkungsverhăltnis verschiedener neuerer Phosphorsäuredünger zu den bisher gebräuchlichen Düngerformen. Bodenk. u. Pflanzenern. 14: 112-132.

(30) - - 1943. Uber die Beeinflussung der Aufnahme und Wirkung verschiedener Phosphatdünger durch eine Kalk-, Magnesiekalk- und Magnesiumsulfatdüngung. Ibid 30: 137-156.

(31) Truog, E. 1916. The utilization of phosphates by agricultural crops, including a new theory regarding the feeding power of plants. Wis. Agr. Exp. Sta. Res. Bul. 41.

(32) UlRich, B. 1959. Theoretische Betrachtungen zur Frage der Rohphosphat-Wirkung. Landw. Forsch. 12: $30-36$.

(33) WRAngelL, M. v. 1922. Gesetzmässigkeiten bei der Phosphorsäureernährung. Landw. Jahrb. 57: $1-78$.

\section{SELOST U S :}

HIENOFOSFAATTI JA SUPERFOSFAATTI NURMIKASVIEN FOSFORIN LÄHTEENÅ

Armi Kail.a

Yliopiston maanviljelyskemian laitos, Helsinki

ja

Pentti Hänninen

Maataloulen tutkimuskeskus, Keski-Suomen liikkuva koetoiminta, Kuusa

Kahdessa kuusivu วtisessa kenttäkokeessa hieta- ja multamailla ei hienofosfaatilla ja superfosfaatilla kolmivuotisesta nurmesta ja sen suojaviljasta saaduissa kokonaissadoissa ollut merkittävää eroa. Sen sijaan niukasti apilaa sisältävän kolmannen vuoden nurmen sadon analysointi osoitti, että hienofosfaatti-koejäseneı heinässä oli vain $0.17 \%$ fosforia kuiva-aineesta, kun taas superfosfaatti oli tuottanut $0.21 \% \mathrm{P}$ sisältävää heinää. Nolla-ruutujen sadon fosforin pitoisuus oli $0.15-0.16 \%$.

Puna-apilan fosforin pitoisuus oli yhtä suuri sekä superfosfaatti- että hienofosfaattiruuduilla, mutta timotei sisälsi hi€nofosfaatilla lannoitettuna vain $0.16 \%$ fosforia, superfosfaattia saaneena taas $0.21 \%$.

Erilaisen lannoitulssen aiheuttamat erot kasvien fosforin pitoisuudessa kytkeytyivät miltei täydellisesti eroihin epäorģaanisen fosforifraktion suuruudessa.

Fosforilannoitus ei vaikuttanut kasvien tuhkan, kalsiumin, kaliumin tai typen pitoisuuteen.

Tutkimuksen tulokset vahvistavat aikaisempaa havaintoa, jonka mukaan hienofosfaatilla lannoitettu apilaton nurmi voi tuottaa eläinten rehuksi ala-arvoista heinäă. Tulokset osoittavat vakuuttavasti, että fosforilannoitteiden vaikutusta tutkittaessa on syytä kiinnittää huomiota myös sadon kemialliseen koostumukseen. 